\title{
Controlled Release Dosage Form
}

National Cancer Institute

\section{Source}

National Cancer Institute. Controlled Release Dosage Form. NCI Thesaurus. Code C42731.

A solid, semi-solid, solution or suspension designed to release active and/or inert ing redient(s) at a controlled rate. 